\title{
The relationship between knowledge of malaria transmission and malaria prevention and the risk of malaria infection in the coastal region of Batam City in Indonesia
}

\author{
Dewi Susanna ${ }^{1 *}$, Tris Eryando ${ }^{2}$ \\ From Parasite to Prevention: Advances in the understanding of malaria \\ Edinburgh, UK. 20-22 October 2010
}

\section{Backgound}

Malaria is still become a serious health problem in Indonesia. The spread of malaria cases are depend on many factors, such as area characteristics or ecological factors. The objective of this study was to assess the relationship between the knowledge of malaria transmission and malaria prevention and the risk of malaria infection in the coastal region of Batam City in Indonesia.

\section{Methods}

The study was conducted in coastal region the coastal region of Batam City in Indonesia, using crossectional design. This research had got the subject 170 in total included cases and non-cases. The case detection based on the microscopy examination. Then, the subjects were asked using a structured questionnaire consisted of 22 questions regarding the knowledge, perception, and practice everything about malaria. The obtained data was managed based on the median of the all answers and then categorized as good and bad knowledge. The collected data analyzed using $\chi^{2}$ test and spatial analyses using nearest neighbours by Thiessen polygons analysis [1].

\section{Results}

There was no significant relationship $(\mathrm{p}>0.05)$ between the variables of general knowledge, malaria transmission, malaria prevention with number of cases and non-cases. The knowledge on malaria transmission did not have

${ }^{1}$ Department of Environmental Health, Faculty of Public Health, University of Indonesia, Depok Campus, Indonesia 16424

Full list of author information is available at the end of the article relationship with malaria incidence (Table 1). From the polygon analysis seemed the distribution of malaria cases and no cases appeared evenly spread throughout the area of research.

\section{Conclusion}

There were not the differences between knowledge of malaria transmission and malaria prevention and the risk of malaria infection in the coastal region. The cases and non cases distribution seemed spread evenly.

Table 1 The Relationship between knowledge of malaria transmission and malaria prevention and the risk of malaria infection in the coastal region of Batam City in Indonesia

\begin{tabular}{lccccc}
\hline & \multicolumn{2}{c}{ Malaria } & & & \\
\cline { 2 - 3 } Variable & Case & Non Case & Total & p value & OR (Cl 95\%) \\
\hline General Knowledge & & & & & \\
Bad & 15 & 65 & 80 & & \\
Good & 11 & 79 & 90 & 0,23 & $1,66(0,66-4,19$ \\
Total & 26 & 144 & 170 & & \\
Transmission & & & & & \\
Bad Knowledge & 18 & 111 & 129 & & \\
Good Knowledge & 8 & 33 & 41 & 0,389 & $0,67(0,25-1,86)$ \\
Total & 26 & 144 & 170 & & \\
Prevention & & & & & \\
Bad Knowledge & 20 & 113 & 133 & & \\
Good Knowledge & 6 & 31 & 37 & 0,860 & $0,93(0,40-2,14)$ \\
Total & 26 & 144 & 170 & & \\
\hline
\end{tabular}

OR, Odds ratio; $\mathrm{Cl}$, Confidence Interval $95 \%$ 


\section{Author details}

${ }^{1}$ Department of Environmental Health, Faculty of Public Health, University of Indonesia, Depok Campus, Indonesia 16424. ${ }^{2}$ Department Biostatistic and Health Informatics, Faculty of Public Health, University of Indonesia, Depok Campus, Indonesia 16424

Published: 20 October 2010

\section{Reference}

1. Lloyd CD: Boca Raton: CRC Press Taylor and Francis Group. Local model for spatial analysis 2007, 94.

doi:10.1186/1475-2875-9-S2-P50

Cite this article as: Susanna and Eryando: The relationship between

knowledge of malaria transmission and malaria prevention and the risk

of malaria infection in the coastal region of Batam City in Indonesia.

Malaria Journal 2010 9(Suppl 2):P50.

Submit your next manuscript to BioMed Central and take full advantage of:

- Convenient online submission

- Thorough peer review

- No space constraints or color figure charges

- Immediate publication on acceptance

- Inclusion in PubMed, CAS, Scopus and Google Scholar

- Research which is freely available for redistribution

Submit your manuscript at www.biomedcentral.com/submit 